\title{
OCCUPATIONAL HEALTH AND SAFETY PRACTICES IN CAPE COAST METROPOLIS
}

\author{
Daniel Ebo HAGAN ${ }^{1}$, Zakari MUSTAPHA ${ }^{2 *}$, \\ Benjamin Boahene AKOMAH ${ }^{3}$, Peter Kobina AIDOO \\ ${ }^{1-4}$ Department of Building Technology, School of Engineering, Cape Coast Technical \\ University, Cape Coast, Ghana \\ "Corresponding author's email: mustapha.zakari@cctu.edu.gh
}

\begin{abstract}
The rate of construction accidents in the Ghanaian construction industry is not encouraging. The study sought to identify the factors affecting the effective health and safety practices in the construction industry within the Cape Coast Metropolis. Purposive sampling technique was used to select the construction firms and 'Yamane formula' to arrive at the number of respondents (44) for the study. Structured questionnaires were distributed among site engineers, site supervisors, safety officers, quantity surveyors, foremen, chief masons and chief carpenters. Statistical Packages for the Social Sciences (SPSS) was used for the data analysis and results were presented in a form of descriptive and inferential statistics. Findings show that the level of health and safety practices within the Metropolis was high and the factors that affected the implementation of health and safety programmes were severe among the firms. Few of the company's health and safety programmes were effective and this calls for the strengthenig of the construction sector policy by the ministries responsible for implementation.
\end{abstract}

Keywords: Accidents, construction industry, Ghana, injuries, risk.

\section{INTRODUCTION}

The construction industry is significant in terms of its socio-economic contribution (Dakhil, 2013). Many construction workers have died in the course of their employment and many more have sustained various degrees of injuries (International Labour Organisation report (ILO, 2010)). Occupational health and safety (OHS) issues are a major challenge to the Ghanaian government (Mustapha et al., 2018). Construction is risky and prone to health and safety risks. This is attributable to the physical environment and the nature of work, operational methods and the use of heavy equipment, and physical properties of the construction project itself (Menzel and Gutierrez, 2010). Accidents in the construction industry have resulted in series of severe injuries, deformations and the most striking of all, death (Quartey \& Puplampu, 2012). Fosu (2019), citing Ayitey, posited that Ghana's construction industry was substantively underdeveloped and as a result, institutional inefficiencies became a common phenomenon. It is essential for the government of Ghana to critically consider establishing a constitutionally mandated regulatory body to ensure the strict adherence to health and safety $(\mathrm{H} \& \mathrm{~S})$ provisions during contract execution (Fosu, 2019). A study conducted by Mustapha et al. (2018) on the Examination of 
Occupational Health and Safety Practices in Ghana concluded that the noncompliance with health and safety rules and regulations within the Ghanaian construction sector was as a result of the non-ratification of the International Labour Organisation (ILO) convention 1981 (No. 115). Bhattacharjee et al. (2011) posited that safety improvement approaches were appropriate measures that could be employed to minimise accidents on sites. The study sought to identify the factors affecting the effective health and safety practices in the construction industry within Cape Coast Metropolis.

\section{HEALTH AND SAFETY PRACTICES AND IMPLEMENTATION PROGRAMMES}

The complex nature of the construction industry is the result of different levels of technology used, the sequential work processes, communication between workers and equipment and the differing levels of safety awareness and training for workers (Bhattacharjee et al., 2011). Datey-Baah and Amponsah-Tawiah (2012) postulated that most of the construction workers who were involved in accidents at the workplace were those who were usually absent at work for days. Several researchers (Orji et al., 2016; Ahmad et al., 2016; Hong et al., 2018) have argued that human factors are the major contributing factors of persistent accidents on construction sites. These factors include improper use of protection equipment (Oji et al., 2016; Kadiri et al., 2014), lack of safety awareness (Goh et al., 2016) and carelessness among workers (Idris, 2016). In addition, some researchers (AbdMutallib, 2014; Hanapi et al., 2013; Goh et al., 2016) have also pointed out poor site management, lack of safety awareness, skill and knowledge in relation to specific work as factors contributing to unsafe actions (Charehzehi \& Ahankoob, 2012). Other factors are lighting system, noise, vibration, weather condition and sunlight. According to Uduakobonge et al. (2016), the major cause of construction accidents is a lack of safety measures in all spheres of activities on site. Tsang et al. (2017) identified working conditions, environmental factors and management actions as the three types of accident related factors. Uduakobonge et al. (2016), on the other hand, perceived demotivation of workers, negative impact on the reputation of firms, enhancing the project cost, damage to plant/equipment and payment for settlement of injury/death claims as accident related factors. Accident can be defined as an unexpected or unplanned event that results in an injury or ill health of an individual, loss or damage to property, materials or environment (HSE, 2016).

Kühn and Rieger (2017) in defining health from the perspective of the WHO stated that health was a state of complete physical, mental and social well-being and not necessarily the absence of disease or infirmity. Hughes and Ferrett (2011) indicated that health involves protection of the body and mind from illness resulting from the materials, processes or workplace procedures. Health and Safety Executive (HSE) (2016) defined welfare as the provision of the necessary facilities to maintain and support the well-being of individuals in the course of their employment engagement. Hughes and Ferrett (2011) defined risk as the possibility of a substance, activity or process to cause harm and hazard which might involve 
chemicals, electricity and working from a ladder, as the ability of a substance, person, activity or process to cause harm.

In a study of health hazards, risk and safety practices in construction sites by Vitharana et al. (2015), it was concluded that health hazards in construction were a result of workers falling from height and electric shocks, exposure to hazardous substances, employees refusal of the use of personal protective equipment (PPE), lack of training facilities, lack of effective labour training, lack of understanding of the job, unsafe behaviour while working with machinery, financial difficulties and influence of alcohol and drugs. Since construction industry stands out among all other industries as the main contributor to accidents and fatalities, improving safety in construction remains a priority (Bhattacharjee et al., 2011). In Ghana, construction sector policy implementation is the mandate of the Ministry of Roads and Transport (MRT) and the Ministry of Water Resources, Works and Housing (MWRWH) (Mustapha et al., 2018).

\section{METHODOLOGY}

This section presents various methods used for the data collection and analysis. Purposive sampling technique was adopted in the selection of five ongoing construction projects in the metropolis (Creswell, 2014). The researchers tried to avoid any bias in their study by choosing only those construction firms that confirmed their preconceptions by administering only fifty questionnaires (Yin, 2011). Obviously, it is stated that the larger the sample, the better it represents the population under study (Mills \& Gay, 2014). A simplified formula of Yamane was used for the derivation of the required number of samples for the study. The minimum number of questionnaires required for the study was derived from Yamane formula:

$$
n=\frac{N}{1+N(e)^{2}},
$$

where $n$ represents the sample size; $N$ is the population size; $e$ is the level of precision, sometimes called sampling error or margin of error. If $N=50$ and $e=0.05$, then $n=44$.

The sample size was approximately 44 at $95 \%$ confidence level. The respondents were site engineers, site supervisors, safety officers, quantity surveyors, foremen, chief masons and chief carpenters. All the variables for the company's health and safety programmes, elements of health and safety programmes and factors that affect the implementation of health and safety programmes were derived from literature. Respondents were asked to rate the given questions either Yes/No or rate the given measures according to a 5-point Likert scale, where $1=$ very important, $2=$ important, $3=$ neutral, $4=$ not important, $5=$ not very important. Statistical Package for Social Sciences (SPSS) was used for the data analysis and results were presented in descriptive and inferential statistics. Frequency distribution tables and charts were also used. 


\section{FINDINGS}

Majority of the respondents were males with post-secondary/tertiary education and their age ranged from 32 to 38 years as shown in Fig. 1.

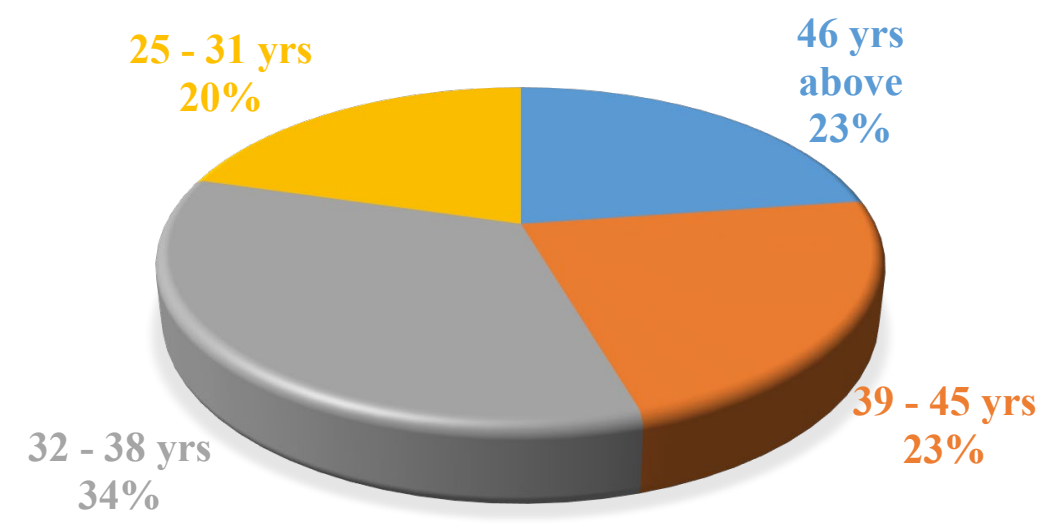

Fig. 1. Age of respondents.

Figure 2 shows that a majority (25\%) of the respondents were quantity surveyors, followed by site engineers and site supervisors. The least group of respondents $(4 \%)$ were chief masons.

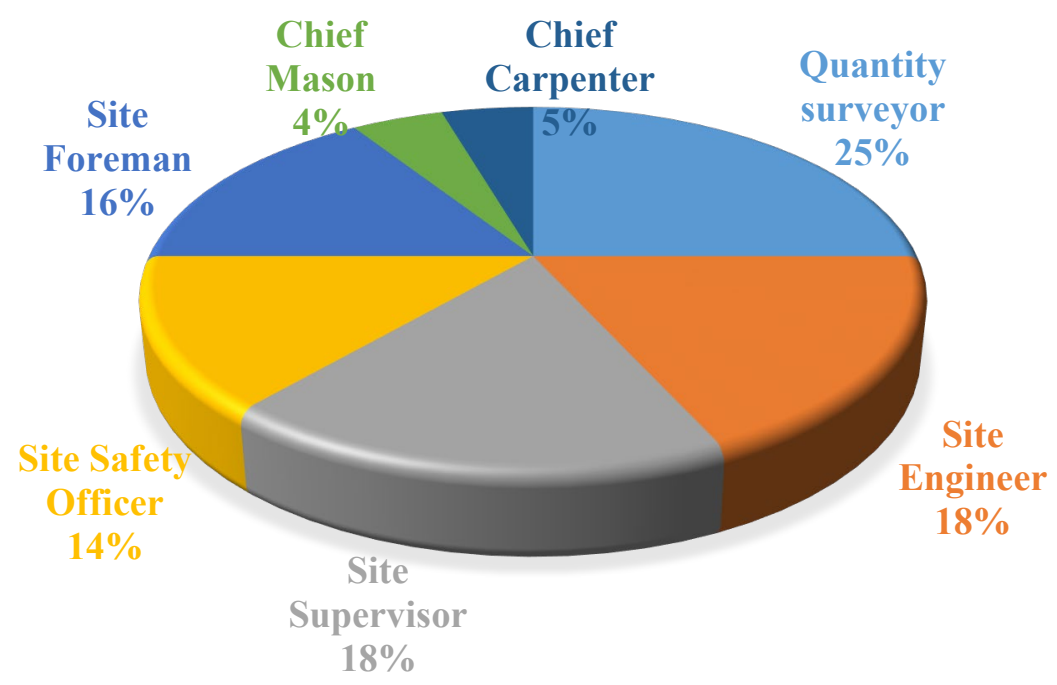

Fig. 2. Position at the construction firm.

Information presented in Table 1 reveals that all the fifteen (15) health and safety programmes were performed by construction firms. The most effective programmes were keeping accident records on site, insurance cover for accidents victims, health and safety training programmes, first aid services for injured workers and visual signals and posters on health and safety. Very few of the respondents were of a negative view towards the company's health and safety 
programmes and few respondents were not sure of the company's health and safety programmes.

Table 1. Company's Health and Safety Programmes

\begin{tabular}{|c|c|c|c|}
\hline Items & Yes, \% & No, $\%$ & $\begin{array}{l}\text { Not Sure, } \\
\%\end{array}$ \\
\hline Accident victims are compensated & $35(79.5)$ & $2(4.5)$ & $7(15.9)$ \\
\hline The company keep records of accidents on site & $40(90.9)$ & $0(0)$ & $4(9.1)$ \\
\hline The company has insurance cover for accident victims & $42(95.5)$ & $0(0)$ & $2(4.5)$ \\
\hline $\begin{array}{l}\text { The company provides full medical coverage for } \\
\text { workers }\end{array}$ & $35(79.5)$ & $5(11.4)$ & $4(9.1)$ \\
\hline $\begin{array}{l}\text { Accidents that occur at the workplace are reported to } \\
\text { the appropriate agencies }\end{array}$ & $30(68.2)$ & $4(9.0)$ & $10(22.7)$ \\
\hline The company replaces injured workers & $30(68.2)$ & $7(15.9)$ & $7(15.9)$ \\
\hline $\begin{array}{l}\text { Health and safety policies are implemented at the } \\
\text { organisation }\end{array}$ & $38(86.4)$ & $2(4.5)$ & $4(9.1)$ \\
\hline The company has a health and safety committee & $35(79.5)$ & $2(4.5)$ & $7(15.9)$ \\
\hline $\begin{array}{l}\text { The company organises health and safety training } \\
\text { programmes }\end{array}$ & $40(90.9)$ & $0(0)$ & $4(9.1)$ \\
\hline $\begin{array}{l}\text { The company has a clinic for the provision of health } \\
\text { services }\end{array}$ & $35(79.5)$ & $5(11.4)$ & $4(9.1)$ \\
\hline $\begin{array}{l}\text { The company provides first aid services to injured } \\
\text { workers }\end{array}$ & $43(97.70$ & $0(0)$ & $1(2.3)$ \\
\hline $\begin{array}{l}\text { The company has visual signals and posters on health } \\
\text { and safety }\end{array}$ & $42(95.5)$ & $0(0)$ & $2(4.5)$ \\
\hline $\begin{array}{l}\text { The company enforces the utilisation of protective } \\
\text { devices }\end{array}$ & $35(79.5)$ & $5(11.4)$ & $4(9.1)$ \\
\hline $\begin{array}{l}\text { There is punishment for those who go against health } \\
\text { and safety policies }\end{array}$ & $25(56.8)$ & $10(22.7)$ & $9(20.5)$ \\
\hline $\begin{array}{l}\text { The company performs regular evaluation and } \\
\text { monitoring of work safety performance }\end{array}$ & $38(86.4)$ & $3(6.8)$ & $3(6.8)$ \\
\hline Average Rating & 33.4 (75.8) & $5.3(12.0)$ & 5.4 (12.2) \\
\hline
\end{tabular}

According to Table 2, four (effective enforcement scheme, safety and health orientation training, written safety and health plan, and appropriate supervision) out of the eleven elements of health and safety programmes were the most effective. They were ranked from $1^{\text {st }}$ to $4^{\text {th }}$ with mean range of 4.05 to 4.39 and standard deviation ranging from 0.878 to 1.140 . The least element (upper management support) was ranked $11^{\text {th }}$ with a mean score of 1.32 and a standard deviation of 0.471 . 
Table 2. Elements of Health and Safety Programmes

\begin{tabular}{lllc}
\hline Item & M & S. Dev & Rank \\
\hline Effective enforcement scheme & 4.39 & 1.017 & $1^{\text {st }}$ \\
Safety and health orientation training & 4.36 & 0.917 & $2^{\text {nd }}$ \\
Written safety and health plan & 4.20 & 0.878 & $3^{\text {rd }}$ \\
Appropriate supervision & 4.05 & 1.140 & $4^{\text {th }}$ \\
Safety equipment acquisition & 3.93 & 1.149 & $5^{\text {th }}$ \\
Maintenance of equipment & 3.89 & 1.166 & $6^{\text {th }}$ \\
Clear and realistic goals & 3.45 & 1.066 & $7^{\text {th }}$ \\
Good communication & 3.34 & 1.180 & $8^{\text {th }}$ \\
Programme evaluation & 3.27 & 1.246 & $9^{\text {th }}$ \\
Continuing participation of employees & 2.80 & 1.153 & $10^{\text {th }}$ \\
Upper management support & 1.32 & 0.471 & $11^{\text {th }}$ \\
\hline
\end{tabular}

M: Mean; S. Dev: Standard deviation

Table 3. Factors Affecting the Implementation of Health and Safety Programmes

\begin{tabular}{lccc}
\hline Item & M & S. Dev & Rank \\
\hline Lack of emergency response plan & 4.39 & 1.017 & $1^{\text {st }}$ \\
Insufficient communication & 4.36 & 0.917 & $2^{\text {nd }}$ \\
Poor personal attitude & 4.36 & 0.917 & $2^{\text {nd }}$ \\
Inadequate evaluation of safety programmes & 4.27 & 0.872 & $4^{\text {th }}$ \\
Absence of safety officers on site & 4.27 & 0.872 & $4^{\text {th }}$ \\
Poor personal motivation & 4.20 & 0.878 & $6^{\text {th }}$ \\
Contractors ignoring safety due to the time pressure of the project & 4.05 & 1.140 & $7^{\text {th }}$ \\
schedule & & & \\
Poor accident record keeping & 3.93 & 1.149 & $8^{\text {th }}$ \\
Poor equipment maintenance & 3.93 & 1.388 & $8^{\text {th }}$ \\
Inefficient training and enforcement systems & 3.93 & 1.388 & $8^{\text {th }}$ \\
Lack of management commitment to safety budget allocation & 3.89 & 1.166 & $11^{\text {th }}$ \\
Lack of workers' self-protection and awareness & 3.45 & 1.066 & $12^{\text {th }}$ \\
Extensive use of foreign workers & 3.34 & 1.180 & $13^{\text {th }}$ \\
Inadequate safety meetings & 3.30 & 1.304 & $14^{\text {th }}$ \\
Extensive subcontracting & 3.30 & 1.304 & $14^{\text {th }}$ \\
Inadequate work procedures & 3.27 & 1.246 & $16^{\text {th }}$ \\
Ineffective site rules and regulations & 3.18 & 1.063 & $17^{\text {th }}$ \\
Uncooperative clients & 2.80 & 1.153 & $18^{\text {th }}$ \\
Lack of enforcement of rules and regulations & 2.77 & 0.886 & $19^{\text {th }}$ \\
\hline M: Mean; S. Dev: Standard deviation & & &
\end{tabular}


Out of the nineteen (19) factors that affect the implementation of health and safety programmes as highlighted in Table 3, seven (7) were rated as most severe. They were ranked from $1^{\text {st }}$ to $7^{\text {th }}$ with mean range of 4.05 to 4.39 and standard deviation ranging from 0.872 to 1.140 . The least (lack of enforcement of rules and regulations) factor was ranked $19^{\text {th }}$ with a mean score of 2.77 and standard deviation of 0.886 .

Table 4 demonstrates the measures that enhance the implementation of health and safety policies. Respondents admitted that the most important factor that could enhance the implementation of health and safety policies was execution of full verification of safety performance, processes and programmes against approved standards as recorded in Table 4. This was ranked $1^{\text {st }}$ with a mean score of 4.36 , and was followed by maintenance of good work environment, approved health and safety standards, and consulting with construction workers and clients on safety matters. These two factors were ranked $2^{\text {nd }}$ with a mean score of 4.27. However, the least ranked measure was provision of adequate supervision to workers, occupying the $16^{\text {th }}$ position with a mean score of 2.77 .

Table 4. Measures Enhancing the Implementation of Health and Safety Practices

\begin{tabular}{|c|c|c|c|}
\hline Item & Mean & S. Dev & Rank \\
\hline $\begin{array}{l}\text { Execution of full verification of safety performance, processes and } \\
\text { programmes against approved standards }\end{array}$ & 4.36 & 0.917 & $1^{\text {st }}$ \\
\hline $\begin{array}{l}\text { Maintenance of good work environment and approved health and } \\
\text { safety standards }\end{array}$ & 4.27 & 0.872 & $2^{\text {nd }}$ \\
\hline Consulting with construction workers and clients on safety matters & 4.27 & 0.872 & $2^{\text {nd }}$ \\
\hline Developing an effective safety reporting system & 4.20 & 0.878 & $4^{\text {th }}$ \\
\hline Provision of effective control of safety and health risks & 4.20 & 0.878 & $4^{\text {th }}$ \\
\hline Assessing potential hazards using public signals & 3.93 & 1.149 & $6^{\text {th }}$ \\
\hline $\begin{array}{l}\text { Ensuring continual involvement of contractors' management, } \\
\text { safety and health practitioners in enhancing safety performance }\end{array}$ & 3.93 & 1.388 & $6^{\text {th }}$ \\
\hline Ensuring safe handling and use of substances and chemicals & 3.93 & 1.388 & $6^{\text {th }}$ \\
\hline $\begin{array}{l}\text { Ensuring that only competent workers carry out construction } \\
\text { works }\end{array}$ & 3.45 & 1.066 & $9^{\text {th }}$ \\
\hline Provision of adequate safety training to workers & 3.34 & 1.180 & $10^{\text {th }}$ \\
\hline Formulating a package for tracking and analysing jobsite accidents & 3.30 & 1.304 & $11^{\text {th }}$ \\
\hline Maintenance of all equipment and plant & 3.30 & 1.304 & $11^{\text {th }}$ \\
\hline $\begin{array}{l}\text { Maintenance of a healthy and safe working environment at all } \\
\text { times }\end{array}$ & 3.27 & 1.246 & $13^{\text {th }}$ \\
\hline Provision of adequate site instructions and information & 3.18 & 1.063 & $14^{\text {th }}$ \\
\hline Ensuring construction tasks are performed in safe manner & 2.80 & 1.153 & $15^{\text {th }}$ \\
\hline Provision of adequate supervision to workers & 2.77 & 0.886 & $16^{\text {th }}$ \\
\hline
\end{tabular}

M: Mean; S. Dev: Standard deviation 


\section{SUMMARY OF FINDINGS}

The most effective company's health and safety programmes performed by all the construction firms were keeping accident records on site, insurance cover for accident victims, health and safety training programmes, first aid services for injured workers and visual signals and posters on health and safety. Lack of an emergency response plan, insufficient communication, poor personal attitude, inadequate evaluation of safety programmes, absence of safety officers on site, poor personal motivation and contractors' ignorance on safety due to the time pressure of the project schedule were found to be the most severe issues among the factors affecting the implementation of health and safety programmes. The most effective factors that can enhance the implementation of health and safety policies were found to be execution of full verification of safety performance, processes and programmes against approved standards, maintenance of good work environment and approved health and safety standards, consulting with construction workers and clients on safety matters, developing an effective safety reporting system and provision of effective control of safety and health risks.

\section{CONCLUSIONS AND RECOMMENDATIONS}

The study sought to identify the factors affecting the effective health and safety practices in the construction industry within the Cape Coast Metropolis. It was revealed that all the firms followed strictly company's health and safety programmes. Few factors were, however, identified to have an effect on the implementation of health and safety programmes, and few factors were effective towards the enhancement of the implementation of health and safety policies. Construction firms should be encouraged to enhance all their health and safety programmes. The Ministries responsible for ensuring the implementation of construction sector policy should strengthen their routine monitoring programmes and broaden the existing health and safety policies to cover the construction industry. The Chamber of Construction Industry should organise annual workshops at the beginning and closing of every year on health and safety to sensitise and educate members on health and safety programmes and evaluate safety performance in the industry based on information submitted to the appropriate health and safety agencies by firms. Point scoring system should be instituted and used to grade construction firms. The result should be published annually in the national dailies for clients and other businesses to know the firms that are safety compliant.

\section{ACKNOWLEDGEMENT}

The authors wish to acknowledge the effort made by Yahaya Issah and Sarfo Kwasi Amoateng during the data collection process. 


\section{REFERENCES}

Abd-Mutallib, I. (2014). The Official Website of Social Security Organisation. http://www.perkeso.gov.my

Ahmad, S., Iraj, M., Abbas, M. \& Mahdi, A. (2016). Analysis of occupational accidents induced human injuries: A case study in construction industries and sites. Journal of Civil Engineering and Construction Technology, 7(1), 1-7. https://doi.org/10.5897/JCECT2015.0379

Bhattacharjee, S., Ghosh, S. \& Young-Corbett, D. (2011). Safety improvement approaches in construction industry: a review and future directions. Proceeding of 47th ASC Annual International Conference.

Charehzehi, A. \& Ahankoob, A. (2012). Enhancement of Safety Performance at Construction Site. International Journal of Advances in Engineering \& Technology, 5(1), 303-312.

Creswell, J. W. (2014). Research design: Qualitative, quantitative and mixed methods approaches. 4th edition. Sage.

Dakhil, A. (2013). The contribution of the construction industry to economic development in Libya. Doctoral dissertation, Liverpool John Moores University.

Datey-Baah, K. \& Amponsah-Tawiah, K. (2012). Government policy and institutional framework for CSR and OSH, In A. K. Jain., B. B. Puplampu., K. Amponsah Tawiah, K., and N. J. A. Andreou. (Eds.), Occupational safety \& health and corporate social responsibility in Africa: Repositioning corporate social responsibility towards national development. Cranfield Press.

Fosu, M. (2019). Improving Construction Health and Safety in Developing Countries (Ghana). GRIN Verlag.

Goh, K. C., Goh, H. H., Toh, T. C. \& Zin A. A. M. (2016). Accidents Preventive Practice for HighRise Construction. MATEC Web of Conferences, 47(2016), 04004. https://doi.org/10.1051/matecconf/20164704004

Hanapi, N. M., Mohd Kamal, M. M., Ismail, M. I. \& Abdullah, I. A. P. (2013). Identifying Root Causes and Mitigation Measures of Construction Fall Accidents. Gading Business and Management Journal, 17(1), 65-79.

Health and Safety Executive (HSE) (2016). Statistics on fatal injuries in the workplace in Great Britain 2016, 1-13.

Hughes, P. \& Ferrett, E. (2011). Introduction to health and safety at work. (5th ed.). Routledge. https://doi.org/10.4324/9780080970714

Idris, S. M. M., (2016). The Star Online. http://www.thestar.com.my/news/nation/2016/03/03/doshfailed-to-instil-safety-culture-at-sites-claims-cap/

International Labour Organization (ILO) (2010). World Day for Safety and Health at Work: Facts on Safety and Health at work. http://www.ilo.org/facts on safety at work.

Kadiri Z. O., Nden, t., Avre G. K., Oladipo T. O., Edom A, Samuel P. O. \& Ananso G. N. (2014). Causes and Effects of Accidents on Construction Sites (A Case Study of Some Selected Construction Firms in Abuja F. C. T Nigeria). IOSR Journal of Mechanical and Civil Engineering, 11(5), 66-72. https://doi.org/10.9790/1684-11516672

Kühn, S., \& Rieger, U. M. (2017). Health is a state of complete physical, mental and social wellbeing and not merely absence of disease or infirmity. Surgery for Obesity and Related Diseases, 13(5), 887. https://doi.org/10.1016/j.soard.2017.01.046

Menzel, N. N. \& Gutierrez, A. P. (2010). Latino worker perceptions of construction risks. American Journal of Industrial Medicine, 53(2), 179-187. https://doi.org/10.1002/ajim.20735

Mills, G. E. \& Gay, L. R. (2014). Educational Research: Competencies for Analysis and Applications. Pearson Education.

Mustapha, Z., Aigbavboa, C. \& Thwala, W. (2018). Examination of Occupational Health and Safety Practices in Ghana. In Arezes P. (eds) Advances in Safety Management and Human Factors. AHFE 2017. Advances in Intelligent Systems and Computing, vol. 604. Springer. https://doi.org/10.1007/978-3-319-60525-8_42

Orji, S. E., Enebe, E. C., \& Onoh F. O. (2016). Accidents in Building Construction Sites in Nigeria; a Case of Enugu State. International Journal of Innovative Research \& Development, 5(3). 
Quartey, S. H. \& Puplampu B. B. (2012). Employee Health and Safety Practices: An Exploratory and Comparative Study of the Shipping and Manufacturing Industries in Ghana. International Journal of Business and Management, 7(23), 81-95. https://doi.org/10.5539/ijbm.v7n23p81

Tsang, Y. T., Fung, I. W. H., Tam, V. W. Y., Sing, C. P. \& Lu, C. T. (2017). Development of an accident modelling in the Hong Kong construction industry. International Journal of Construction Management, 17(2), 124-131. https://doi.org/10.1080/15623599.2016.1222664

Uduakobonge, U. E., Usip, E. E., \& Asuquo, C. F. (2016). Effect of lack of adequate attention to safety measures on construction sites in Akwa Ibom State, Nigeria. Journal of Earth Sciences and Geotechnical Engineering, 6(1), 113-121.

Vitharana, V. H. P., Subashi De Silva, G. H. M. J. \& De Silva, S. (2015). Health Hazards, Risk and Safety Practices in Construction Sites - A Review Study. Engineer, 48(3), 35-44. https://doi.org/10.4038/engineer.v48i3.6840

Yin, R. K. (2011). Applications of case study research. Sage.

Hong Z. \& Gui F. (2018). Analysis on Human Unsafe Acts Contributing to Falling Accidents in Construction Industry. In Arezes P. (eds) Advances in Safety Management and Human Factors. AHFE 2017. Advances in Intelligent Systems and Computing, vol 604. Springer. https://doi.org/10.1007/978-3-319-60525-8_ 19

\section{AUTHOR'S SHORT BIOGRAPHIES}

Daniel Ebo Hagan received both his Master and Bachelor degrees in Architecture from the Kwame Nkrumah University of Science and Technology, Kumasi, Ghana. He is a Lecturer at the Department of Building Technology, Cape Coast Technical University, Cape Coast, Ghana. He is a co-author of some scientific publications. He is an associate member of the Ghana Institute of Architects (GIA). His research interest is in construction management and health and safety. E-mail: dandehag101@yahoo.com

Zakari Mustapha received his Doctoral degree in Engineering Management from the University of Johannesburg, South Africa. He received his Master and Bachelor degrees from the Bayero University, Kano, Nigeria and Federal University of Technology, Yola, Nigeria respectively. He is a Lecturer at the Cape Coast Technical University, Cape Coast, Ghana. He is the author and a coauthor of several scientific publications. He is a cooperate member of the Ghana Institution of Construction (MGIOC).

E-mail: mustapha.zakari@ectu.edu.gh

ORCID iD: https://orcid.org/0000-0002-0653-8739

Benjamin Boahene Akomah is a Senior Lecturer at the Cape Coast Technical University. B. B. Akomah is currently pursuing his $\mathrm{PhD}$ at VIT University in India. He obtained his Master of Philosophy degree in Procurement Management in 2014 from the Kwame Nkrumah University of Science and Technology (KNUST), B. Sc. in Building Technology from the same university in 2008 and his Higher National Diploma in Building Technology from the Cape Coast Polytechnic in 2005. $\mathrm{He}$ is the co-author of several scientific publications. He is a corporate member of the Ghana Institution of Construction and Institution of Engineering and Technology.

E-mail: benjamin.akomah@,cctu.edu.gh

ORCID iD: https://orcid.org/0000-0002-2701-2867

Peter Kobina Aidoo received his Bachelor degree in Building Technology from the Kwame Nkrumah University of Science and Technology (KNUST), Kumasi, Ghana; and his Higher National Diploma in Building Technology from the Cape Coast Polytechnic. He is an instructor at the Cape Coast Technical University.

E-mail: Pekaid10@yahoo.com 